Maharani, M., \& Ampuni, S. (2020). Perilaku anti sosial remaja laki-laki ditinjau dari identitas moral dan moral disengagement. Indigenous: Jurnal Ilmiah Psikologi, 5(1). 53-65. doi: https://doi. org/10.23917/indigenous.v5i1.8706

\title{
Perilaku Anti Sosial Remaja Laki-laki ditinjau dari Identitas Moral dan Moral Disengagement
}

\author{
Meyrantika Maharani ${ }^{1}$, Sutarimah Ampuni ${ }^{2}$ \\ Universitas Gajah Mada ${ }^{12}$ \\ meyrantika95@gmail.com¹, s.ampuni@ugm.ac.id ${ }^{2}$
}

\begin{abstract}
This research aimed to examine the role of moral identity and moral disengagement on antisocial behavior in male adolescents. It was hypothesized that moral identity and moral disengagement would contribute to antisocial behavior; lower moral identity and higher moral disengagement would lead to higher antisocial behavior, and vice versa. Moral Identity Scale, Moral Disengagement Scale, and Antisocial Behavior Scale were used to measure students' moral identity, moral disengagement, and antisocial behavior, respectively. Participants were 121 male students from two high schools in Yogyakarta City selected using a convenience sampling technique. The result showed that, as expected, moral identity and moral disengagement contributed significantly to antisocial behavior $\left(R^{2}=0,12 ; F=8,19 ; t=3,86\right.$; $p<0,01)$. Lower moral identity $(b=-0,55 ; t=-2,08 ; p<0,05)$ and higher moral disengagement $(b=$ $0,29 ; t=2,49 ; p<0,05)$ led to increasing antisocial behavior.
\end{abstract}

Keywords: antisocial behavior; male adolescent; moral disengagement; moral identity

Abstraksi. Penelitian ini bertujuan untuk mengetahui peran identitas moral dan moral disengagement terhadap perilaku anti sosial pada remaja laki-laki. Hipotesis yang diajukan adalah identitas moral dan moral disengagement berperan terhadap perilaku anti sosial; jika identitas moral tinggi dan moral disengagement rendah, maka perilaku anti sosial akan rendah, demikian pula sebaliknya. Alat ukur yang digunakan adalah Skala Identitas Moral, Skala Moral Disengagement, dan Skala Perilaku Anti Sosial. Partisipan adalah 121 siswa laki-laki di dua SMA di Yogyakarta yang dipilih menggunakan teknik convenience sampling. Hasil penelitian menunjukkan bahwa identitas moral dan moral disengagement secara simultan berperan terhadap perilaku anti sosial $\left(R^{2}=0,12 ; F=8,19 ; t=3,86\right.$; $p<0,01)$. Semakin rendah Identitas moral $(b=-0,55 ; t=-2,08 ; p<0,05)$ dan semakin tinggi moral disengagement $(b=0,29 ; t=2,49 ; p<0,05)$ maka perilaku anti sosial akan semakin tinggi.

Katakunci: identitas moral; moral disengagement; perilaku anti sosial; remaja laki-laki

\section{PENDAHULUAN}

Masa remaja merupakan masa transisi dalam rentang kehidupan manusia dan merupakan penghubung masa kanak-kanak dan masa dewasa (Santrock, 2017). Salah satu karakteristik masa remaja adalah berkurangnya komunikasi dengan orang tua dan beralih pada teman sebaya untuk memenuhi kebutuhannya (Santrock, 2017). Berkaitan dengan perkembangan perilaku sosial ini, salah satu masalah yang seringkali dihadapi remaja adalah keterlibatan dengan kelompok pertemanan yang negatif, atau kelompok sebaya yang terlibat perilaku menyimpang (Wakoli dkk., 2016). Perilaku menyimpang yang dilakukan remaja sering disebut sebagai perilaku anti sosial.

Perilaku anti sosial merupakan perilaku melanggar norma yang berdampak negatif terhadap

54 | Perilaku anti sosial... 
masyarakat (Bushman \& Baumeister, 2007). Menurut Harradine, Kodz, Lemetti dan Jones (2004), jenis perilaku anti sosial meliputi penyalahgunaan ruang publik, mengabaikan keselamatan masyarakat, mengabaikan kesejahteraan pribadi, tindakan berbahaya yang ditujukan pada orang lain, dan perusakan lingkungan. Perilaku anti sosial remaja dapat berupa tindakan-tindakan yang lebih ringan, yang seringkali dikenal sebagai kenakalan remaja, namun dapat pula bersifat lebih berat bahkan mengarah pada tindakan kriminal yang serius.

Berdasar data dari Badan Pusat Statistik (2010) di Indonesia, persentase remaja usia 13-17 tahun yang melakukan tindak pidana meningkat dari tahun ke tahun. Pada tahun 2007, tercatat sekitar 3100 remaja yang terlibat dalam kasus kriminalitas, kemudian pada tahun 2008 dan 2009 meningkat menjadi 4.200 remaja (BPS, 2010). Yang paling banyak terlibat tindak pidana adalah remaja yang berusia 17 tahun (39\%), disusul remaja berusia 16 tahun (30\%), kemudian remaja 15 tahun $(16 \%)$.

Tidak hanya dari segi kuantitas, laporan Badan Pusat Statistik (2010) juga menjelaskan bahwa tindak kriminalitas yang dilakukan oleh remaja juga meningkat secara kualitas. Perilaku anti sosial yang dilakukan remaja pada awalnya hanya berupa tawuran atau perkelahian antar teman, namun sekarang berkembang menjadi tindak kriminalitas seperti pencurian, pemerkosaan, penggunaan narkoba hingga pembunuhan (BPS, 2010).

Lebih lanjut, data menunjukkan bahwa sebanyak 94\% perilaku anti sosial pada remaja dilakukan oleh laki-laki, dan hanya 6\% yang dilakukan oleh perempuan (BPS, 2010). Meskipun perilaku anti sosial dapat dilakukan oleh laki-laki maupun perempuan, pada umumnya laki-laki memang lebih mendominasi (Kartono, 2009). Dominasi remaja laki-laki pada perilaku anti sosial merupakan fenomena umum yang terjadi juga di negara lain (Moffitt dkk., 2001). Penelitian Moffitt dkk. (2001) menunjukkan bahwa adanya perbedaan pada faktor neurodevelopmental mengakibatkan remaja laki-laki menjadi lebih berani dalam mengambil resiko dibandingkan dengan perempuan sehingga laki-laki lebih sering berperilaku anti sosial.

Perilaku anti sosial remaja sangat erat kaitannya dengan perkembangan identitas diri remaja. Menurut teori psikososial, masa remaja berada pada tahap krisis identitas versus kebingungan identitas. Pada masa ini, remaja melakukan banyak percobaan (trial and error) untuk menemukan dan mengembangkan identitas dirinya (Erikson, dalam Feist \& Feist, 2009). Perilaku anti sosial pada remaja mungkin merupakan salah satu bentuk dari proses trial and error yang kurang dilandasi dengan nilai dan norma.

Internalisasi nilai dan norma adalah satu bagian dari proses pembentukan identitas moral, yang merupakan salah satu bagian penting dari identitas diri. Menurut Hardy dan Carlo (2011) identitas moral merupakan bagian dari identitas diri yang berisi identifikasi nilai-nilai dan normanorma. Dengan kata lain, identitas moral merupakan sejauh mana moralitas menjadi bagian penting dari identitas seseorang (Hardy \& Carlo, 2011). Aquino dan Americus Reed (dalam Reynolds \& Ceranic, 2007) mengkategorikan identitas moral menjadi dua aspek, yaitu internalisasi dan simbolisasi. Internalisasi menunjukkan sejauh mana perilaku yang bermoral menjadi perilaku inti pada individu sehingga sudah menetap di dalam dirinya. Sedangkan simbolisasi menunjukkan sejauh mana sifat-sifat individu ditunjukkan melalui tindakannya secara nyata. Menurut Aquino dan Americus Reed (2002) identitas moral secara efektif dapat berperan terhadap munculnya perilaku moral. Ketika moralitas telah menyatu dengan identitas seseorang, maka pikiran dan perilakunya akan dilandasi oleh nilai-nilai moralitas tersebut (Colby \& Damon, 1992).

Penelitian yang dilakukan oleh Hardy dkk. (2015) dengan sampel sebanyak 384 remaja meneliti kaitan antara perilaku prososial dan perilaku anti sosial dengan identitas moral dan regulasi diri. Penelitian tersebut menemukan bahwa remaja yang memiliki identitas moral rendah 
cenderung lebih berperilaku amoral dan juga lebih mungkin untuk berperilaku anti sosial (Hyde, dalam Hardy dkk., 2015).

Selain identitas moral, moral disengagement juga merupakan faktor lain yang berasosiasi dengan munculnya perilaku anti sosial. Penelitian Kavussanu dkk. (2015) membuktikan bahwa perilaku anti sosial muncul karena adanya moral disengagement yang dapat membenarkan perilaku mereka yang melanggar norma. Hal tersebut menyebabkan seseorang menjadi tidak memiliki rasa bersalah saat melakukan tindakan anti sosial.

Moral disengagement didefinisikan sebagai ketidakaktifan regulasi diri sehingga individu tidak memiliki rasa bersalah ketika perilakunya melanggar standar moral internal (Bandura, 2002). Terdapat delapan mekanisme yang saling berkaitan dalam moral disengagement, meliputi justifikasi moral, euphemistic labeling, perbandingan yang menguntungkan, melempar tanggung jawab, difusi tanggung jawab, mendistorsi konsekuensi, selalu menyalahkan pihak lain, dan dehumanisasi (Bandura, 2002).

Justifikasi moral merupakan mekanisme moral disengagement pada individu yang melakukan tindakan tidak bermoral kepada dirinya atau orang lain namun tindakan tersebut dibenarkan oleh dirinya. Individu tersebut menjadi tidak memiliki rasa bersalah atas tindakan yang dilakukan. Contohnya seperti membenarkan merampok dengan alasan untuk menafkahi keluarganya.

Euphemistic labeling yaitu seseorang menggunakan bahasa yang halus untuk membuat suatu perilaku negatif menjadi perilaku yang terlihat baik. Hal tersebut disebabkan karena bahasa membentuk pola pikir orang lain yang didasarkan pada tindakannya, sehingga bahasa dianggap sebagai alat untuk "masking" pada tindakan negatif (Bolinger, dalam Bandura \& Claudio Barbaranelli dkk., 1996). Misalnya, seseorang yang mengambil barang orang lain tanpa izin lalu mengatakan "saya hanya bermaksud meminjam bukan mencuri, jadi saya tidak salah"

Perbandingan yang menguntungkan merupakan sikap seseorang yang membandingkan pelanggaran moral yang dilakukannya dengan pelanggaran yang lebih berat sehingga individu tersebut menganggap perilakunya benar (Bandura \& Jourden, 1991). Contohnya, "sekedar mengumpat seseorang tidak masalah, daripada memukulnya."

Melempar tanggung jawab merupakan perbuatan seseorang yang tidak ingin disalahkan dari tanggung jawab karena adanya atasan atau orang lain yang memiliki otoritas yang lebih tinggi yang seharusnya bertanggung jawab. Misalnya, seorang anak yang memukuli temannya tidak merasa bersalah karena merasa hanya menjalankan perintah dari kakak kelasnya.

Difusi tanggung jawab merupakan mekanisme di mana seorang individu merasa bahwa kesalahan yang ia lakukan bukan kesalahannya sendiri tetapi juga kesalahan orang lain. Dalam suatu kelompok, tidak ada satu anggota secara pribadi yang merasa bertanggung jawab terhadap apa yang terjadi dalam kelompok tersebut. Misalnya, ketika terjadi tawuran antarkelompok, orang akan berperilaku nekad karena merasa berada di bawah tanggung jawab kelompok (Bandura \& Claudio Barbaranelli dkk., 1996).

Mendistorsi konsekuensi adalah menganggap remeh perbuatan salah yang telah dilakukan, menganggap bahwa itu hanya hal kecil (Bandura \& Claudio Barbaranelli dkk., 1996). Misalnya seorang bendahara yang mengambil sedikit uang dari kas organisasinya dan berpikir bahwa hal itu tidak salah karena toh organisasi punya uang banyak.

Menyalahkan pihak lain terjadi karena dirinya tidak ingin disalahkan sehingga selalu melempar kesalahan kepada orang lain atas pelanggaran moral yang dilakukannya (Ferguson \& Rule dalam Bandura \& Claudio Barbaranelli dkk., 1996). Contohnya, seseorang yang ketahuan menyontek kemudian menyalahkan teman yang memberinya contekan dan membela dirinya 
sendiri.

Dehumanisasi yaitu saat seseorang melakukan kesalahan pada orang lain namun tidak merasa bersalah karena menganggap orang lain tersebut rendah seperti benda atau binatang yang tidak memiliki perasaan dan harapan, sehingga pantas untuk diperlakukan secara tidak manusiawi (Kelman, dalam Bandura dkk., 1996). Misalnya, seseorang yang memperlakukan pembantunya secara semena-mena namun tidak merasa bersalah karena menganggap orang tersebut derajatnya rendah selayaknya binatang piaraannya.

Berdasarkan paparan di atas, identitas moral dan moral disengagement dimungkinkan merupakan faktor yang berperan terhadap munculnya perilaku anti sosial remaja. Remaja yang memiliki identitas moral yang kuat akan tidak mudah untuk berperilaku anti sosial karena adanya nilai dan norma yang telah melekat dalam identitas dirinya. Di sisi lain, remaja yang memiliki kecenderungan moral disengagement tidak memiliki rasa bersalah ketika perilakunya melanggar norma, termasuk saat berperilaku anti sosial.

Penelitian ini mengambil fokus pada remaja di Kota Yogyakarta. Hal ini didasarkan pada pertimbangan bahwa perilaku anti sosial remaja di kota tersebut tercatat sangat tinggi. Dalam beberapa tahun terakhir terdapat kasus-kasus perilaku anti sosial dari yang bertaraf biasa hingga yang ekstrim. Kasus perilaku anti sosial ekstrim yang terjadi di Yogyakarta antara lain kasus klithih dan pembunuhan. Sepanjang tahun 2019, terjadi beberapa kasus klithih oleh remaja di Yogyakarta dan sekitarnya. Klithih yang dilakukan berupa pelemparan batu yang dilakukan oleh sekelompok remaja hingga korban mengalami pecah tengkorak (Santoso, 2019), menendang orang tak dikenal berkali-kali dan melukai korban dengan pedang (Hadi, 2019), pembacokan kepala oleh tiga remaja berusia 15 dan 17 tahun (Suharjono, 2019), bahkan sekelompok remaja melempar cat dan menendang seorang remaja tidak dikenal hingga berakibat kematian hanya karena iseng (Yuwono, 2020). Lebih lanjut, menurut data Badan Pusat Statistik Provinsi D.I. Yogyakarta (2019), tindak kejahatan remaja di D.I. Yogyakarta paling banyak dilakukan di Kota Yogyakarta yaitu sebanyak 2141 kasus (35\%), disusul Sleman sebanyak 2088 kasus (35\%), kemudian Bantul sebanyak 887 kasus (15\%).

Kasus-kasus di atas menunjukkan bahwa fenomena ini sangat krusial untuk diatasi. Penelitian-penelitian sangat penting dilakukan untuk menemukan berbagai solusi. Belum terdapat penelitian mengenai perilaku anti sosial dengan identitas moral dan moral disengagement baik di Indonesia secara umum maupun di Yogyakarta. Penelitian ini menguji apakah tingginya perilaku anti sosial ini dipengaruhi oleh identitas moral yang rendah dan moral disengagement yang tinggi, khususnya pada remaja laki-laki di Kota Yoyakarta. Hipotesis yang diajukan dalam penelitian ini adalah identitas moral dan moral disengagement berperan terhadap perilaku anti sosial; jika identitas moral tinggi dan moral disengagement rendah, maka perilaku anti sosial akan rendah. Demikian pula sebaliknya, jika identitas moral rendah dan moral disengagement tinggi, maka perilaku anti sosial akan tinggi.

\section{METODE}

Subjek dalam penelitian ini adalah 121 remaja laki-laki yang merupakan siswa dari dua sekolah negeri (satu SMA dan satu SMK) di Yogyakarta. Subjek berusia 15 tahun $(N=33), 16$ tahun $(N=63), 17$ tahun $(N=23)$, dan 18 tahun $(N=2)$. Kedua sekolah tersebut dipilih karena di antara siswanya ada yang tercatat terlibat aksi klithih, sehingga dimungkinkan siswa-siswanya memiliki risiko perilaku anti sosial. Peneliti mendapatkan perizinan formal sesuai prosedur yang berlaku, kemudian guru BK mengarahkan peneliti untuk mengambil data di kelas XI.

Perilaku anti sosial diukur dengan menggunakan Skala Perilaku Anti Sosial yang dimodifikasi 
dari skala milik Allsopp dan Feldman (1976) serta Burt dan Donnellan (2009). Skala Perilaku Anti Sosial terdiri dari 36 aitem dengan empat pilihan jawaban yaitu tidak pernah, 1-2 kali, 3-4 kali, dan lebih dari 5 kali. Contoh aitemnya adalah "Menyalakan petasan di jalan atau di tempat yang tidak seharusnya”. Skala ini memiliki koefisien korelasi aitem total bergerak dari 0,21-0,69 dan reliabilitas Alpha sebesar 0,88.

Identitas moral diukur dengan menggunakan Skala Identitas Moral yang diterjemahkan dari skala milik Aquino dan Americus Reed (2002) yang terdiri dari 10 aitem dengan 5 pilihan jawaban yaitu dari sangat tidak setuju (1) hingga sangat setuju (5). Sebelum mengisi skala, subjek diminta untuk membayangkan seseorang yang memiliki beberapa karakteristik seperti perhatian, penyayang, adil, ramah, murah hati, suka menolong, kerja keras, jujur, dan baik. Contoh aitem pada Skala Identitas Moral adalah "Hal yang saya lakukan di waktu luang (misal: hobi) menunjukkan diri saya sebagai orang yang memiliki karakteristik tersebut”. Skala Identitas Moral memiliki reliabilitas Alpha sebesar 0,75 dengan koefisien korelasi aitem-total bergerak dari 0,32 - 0,67.

Moral disengagement diukur menggunakan Skala Moral terjemahan dari skala milik (Bandura \& National Institute of Mental Health, 1986). Skala ini terdiri dari 28 aitem dengan 5 pilihan jawaban mulai dari sangat tidak setuju (1) hingga sangat setuju (5). Contoh aitem pada skala ini yaitu "Menampar dan mendorong seseorang merupakan cara dalam bercanda". Skala ini memiliki reliabilitas Alpha sebesar 0,87 dan koefisien korelasi aitem-total bergerak dari 0,30-0,62.

Metode analisis data yang digunakan dalam penelitian ini adalah analisis regresi berganda dengan menggunakan software IBM SPSS versi 22.0 for Windows.

\section{HASIL DAN PEMBAHASAN}

Tabel 1.

Skor hipotetik dan skor empirik pada variabel perilaku anti sosial, identitas moral, dan moral disanggement

\begin{tabular}{lcccccccc}
\hline \multicolumn{1}{c}{ Variabel } & \multicolumn{4}{c}{ Skor Hipotetik } & \multicolumn{4}{c}{ Skor Empirik } \\
& Xmin & Xmax & Mean & SD & Xmin & Xmax & Mean & SD \\
\hline Perilaku anti sosial & 34 & 136 & 85 & 17 & 34 & 110 & 56,05 & 1,46 \\
Identitas moral & 10 & 50 & 30 & 6,67 & 15 & 50 & 38,92 & 0,51 \\
Moral disengagement & 28 & 140 & 84 & 18,67 & 29 & 103 & 68,12 & 1,17 \\
\hline
\end{tabular}

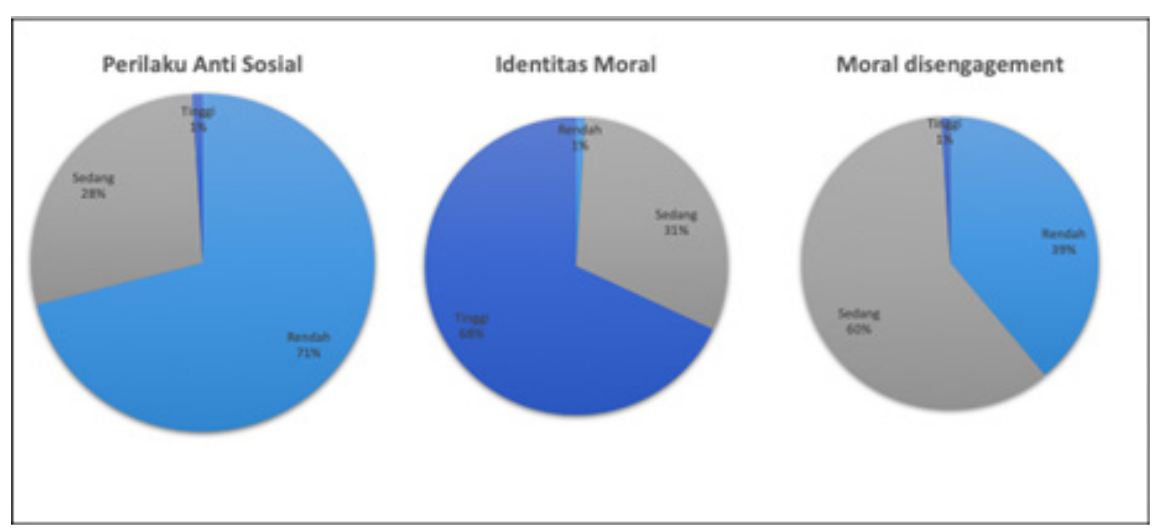

Gambar 1. Kategorisasi Data Penelitian

Deskripsi Data. Deskripsi data selengkapnya dapat dilihat pada Tabel 1. Kategorisasi data penelitian (Gambar 1) menggunakan norma hipotetik menunjukkan bahwa perilaku anti sosial subjek sebagian besar berada dalam kategori rendah, yaitu sebanyak 86 subjek (71\%), sedangkan yang lain berada pada kategori sedang (28\%) dan tinggi (1\%). Pada variabel identitas moral, sebagian 
besar subjek berada pada kategori tinggi, yaitu sebanyak 82 subjek (68\%). Pada variabel moral disengagement, 73 subjek (60\%) berada dalam kategori sedang. Berdasarkan kategorisasi tersebut, hanya ada satu subjek (1\%) yang menunjukkan perilaku anti sosial dan moral disengagement yang tinggi.

Tabel 2.

Perbedaan skor perilaku anti sosial berdasarkan karakteristik demografis $(\mathrm{N}=121)$

\begin{tabular}{llllll}
\hline & Karakteristik & $M$ & $S D$ & $F$ & $p$ \\
\hline Usia & 15 tahun $(N=33)$ & 49,3 & 13,7 & 2,87 & $0,04^{*}$ \\
& 16 tahun $(N=63)$ & 58,6 & 17,1 & & \\
& 17 tahun $(N=23)$ & 58,8 & 14,5 & & \\
Pe nd id i k a n & SD $(N=12)$ & 54 & 2,8 & & \\
Terakhir Ayah & SMP $(N=14)$ & 56,6 & 17,0 & 0,31 & 0,93 \\
& SMA/sederajat $(N=40)$ & 54,1 & 12,5 & & \\
& D3 $(N=3)$ & 56,9 & 15,3 & & \\
& Sarjana $(N=14)$ & 51,4 & 14,9 & & \\
Pe nd id i k a n & Tidak tahu $(N=33)$ & 51,4 & 12,2 & & \\
Terakhir Ibu & SD $N=14)$ & 56,9 & 19,3 & & \\
& SMP $(N=13)$ & 56,6 & 15,9 & 0,58 & \\
& SMA/sederajat $(N=45)$ & 51,5 & 11,2 & & \\
& D3 $(N=2)$ & 56,1 & 14,2 & & \\
& Sarjana $(N=14)$ & 43,0 & 0,0 & & \\
& Tidak tahu $(N=33)$ & 56,6 & 15,0 & & \\
\hline
\end{tabular}

Hasil one-way between group analysis of variance (ANOVA) memperlihatkan bahwa terdapat perbedaan perilaku anti sosial pada remaja laki-laki berdasarkan usia $(F=2,865$; $p<0,05)$. Perhitungan post-hoc multiple comparisons pada kelompok usia subjek (Tabel 3) menunjukkan perilaku anti sosial ditemukan paling rendah pada usia 15 tahun $(M=49,3 ; S D=13,7)$ namun tidak ada perbedaan perilaku anti sosial pada usia 16, 17 dan 18 tahun. Sebagai tambahan, perbedaan perilaku antisosial berdasarkan tingkat pendidikan orangtua juga diuji, namun hasilnya menunjukkan tidak ada perbedaan yang signifikan. Hasil one-way between group ANOVA tersebut dapat dilihat pada Tabel 2.

Tabel 3.

Hasil uji post-hoc perbedaan perilaku anti sosial berdasarkan usia

\begin{tabular}{ccccc}
\hline & Usia & Mean Difference & Std. Error & Sig. \\
\hline \multirow{3}{*}{15 tahun } & 16 tahun & $-9,33$ & 3,37 & 0,01 \\
& 17 tahun & $-9,52$ & 4,26 & 0,03 \\
\multirow{3}{*}{16 tahun } & 18 tahun & $-4,70$ & 11,41 & 0,68 \\
& 15 tahun & 9,33 & 3,37 & 0,01 \\
& 17 tahun & $-0,19$ & 3,82 & 0,96 \\
\multirow{3}{*}{17 tahun } & 18 tahun & 4,64 & 11,25 & 0,68 \\
& 15 tahun & 9,52 & 4,26 & 0,03 \\
\multirow{3}{*}{18 tahun } & 16 tahun &,- 19 & 3,82 & 0,96 \\
& 18 tahun & 4,83 & 11,55 & 0,68 \\
& 15 tahun & 4,70 & 11,41 & 0,68 \\
& 16 tahun & $-4,64$ & 11,25 & 0,68 \\
& 17 tahun & $-4,83$ & 11,55 & 0,68 \\
\hline
\end{tabular}


Tabel 4.

Korelasi antar variabel

\begin{tabular}{lcll}
\hline Variabel & Perilaku anti sosial & Identitas moral & Moral disengagement \\
\hline Perilaku anti sosial & 1,00 & $-0,28^{* * *}$ & $0,29^{* * *}$ \\
Identitas moral & & 1,00 & 1,00 \\
$-0,36^{* * *}$ Moral disengagement & & & 1,00 \\
\hline
\end{tabular}

Uji Hipotesis. Uji asumsi yang dilakukan sebelum uji hipotesis menunjukkan bahwa persebaran data pada Skala Perilaku Anti Sosial, Skala Identitas Moral, dan Skala MoralDisengagement terdistribusi normal. Uji linearitas menunjukkan bahwa terdapat hubungan yang linear antara perilaku anti sosial dengan identitas moral $(F=10,17 ; p<0,05)$, serta antara Skala Perilaku Anti Sosial dengan Skala Moral Disengagement $(F=11,52 ; p<0,05)$. Korelasi antar variabel (Tabel 4$)$ menunjukkan bahwa terdapat hubungan negatif yang signifikan antara perilaku anti sosial dengan identitas moral $(r=-0,26 ; p<0,01)$ dan hubungan positif yang signifikan antara perilaku anti sosial dengan moral disengagement $(r=0,29 ; p<0,01)$.

${ }^{*} p<0,05 ;{ }^{* *} p<0,01 ;{ }^{* * *} p<0,001$

Tabel 5.

Ringkasan hasil analisis regresi

\begin{tabular}{lllclcr}
\hline \multicolumn{1}{c}{ Model } & $\mathrm{R}^{2}$ & $\mathrm{~B}$ & Std. Error & $\mathrm{t}$ & $\mathrm{F}$ & Sig. \\
\hline (Constant) & 0,12 & 57,90 & 15,01 & 3,86 & 8,193 & 0,00 \\
Moral Disengagement & & 0,29 & 0,12 & 2,49 & & 0,01 \\
Identitas Moral & & $-0,55$ & 0,26 & $-2,08$ & & 0,04 \\
\hline
\end{tabular}

Uji hipotesis dengan analisis regresi melalui metode enter (Tabel 5) menunjukkan bahwa identitas moral dan moral disengagement secara bersama-sama berperan signifikan terhadap perilaku anti sosial $\left(R^{2}=0,12 ; F=8,19 ; t=3,86 ; p<0,01\right)$. Identitas moral berkontribusi sebesar $5 \%(b=$ $-0,55 ; t=-2,08 ; p<0,05)$ terhadap perilaku anti sosial, sedangkan moral disengagement berkontribusi sebesar $7 \%(b=0,29 ; \mathrm{t}=2,49 ; p<0,05)$ terhadap perilaku anti sosial.

Dapat diartikan bahwa sesuai yang dihipotesiskan, jika identitas moral tinggi dan moral disengagement rendah, maka perilaku anti sosial rendah. Sebaliknya, jika identitas moral rendah dan moral disengagement tinggi, maka perilaku anti sosial pada remaja laki-laki akan tinggi. Model ini menunjukkan peran identitas moral dan moral disengagement terhadap varians perilaku anti sosial sebesar $12 \%\left(R^{2}=0,12\right)$.

Setelah mengetahui bahwa regresi terbukti signifikan, peneliti menguji apakah kedudukan variabel identitas moral dan moral disengagement bersifat sejajar sebagai prediktor ataukah moral disengagement lebih merupakan mediator antara identitas moral dan perilaku anti sosial. Untuk pengujian ini, dilakukan analisis mediasi sederhana melalui teknik PROCESS yang dikembangkan oleh Hayes (2013).

Menurut Baron dkk. (1986), suatu variabel dapat dikatakan berfungsi menjadi mediator penuh jika memenuhi tiga syarat. Syarat pertama, variance pada variabel independen $(\mathrm{X})$ memiliki peran yang signifikan terhadap variance pada mediator $(\mathrm{M})$, disebut dengan jalur a. Syarat kedua, variance pada $\mathrm{M}$ berperan secara signifikan pada variabel dependen $(\mathrm{Y})$, atau disebut dengan jalur b. Syarat ketiga, saat jalur a dan b dikontrol, peran X terhadap Y yang awalnya signifikan (jalur c) menjadi tidak signifikan (jalur c'). jika jalur c' tetap signifikan dengan koefisien regresi c' lebih kecil dari koefisien regresi c, maka disebut dengan mediasi parsial. 
Dalam pengujian ini, hasil menunjukkan bahwa syarat pertama terpenuhi yaitu jalur a signifikan $(b=-0,83 ; p<0,01)$, begitu juga dengan syarat kedua terpenuhi yaitu jalur $b$ siginifikan $(b=0,29 ; p<0,01)$. Jalur c juga signifikan $(b=-0,78 ; p<0,01)$; nilai c' lebih rendah dari nilai c, tetapi tetap signifikan $(b=-0,55 ; p<0,05)$, dengan demikian dapat diartikan moral disengagement memediasi secara parsial peran identitas moral terhadap perilaku anti sosial.

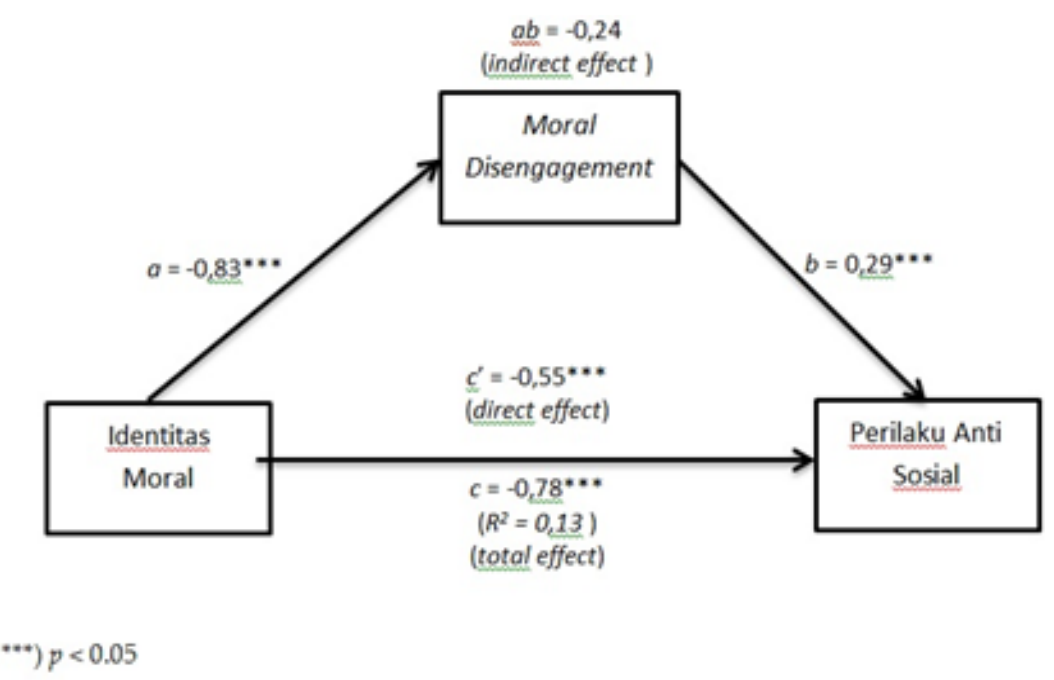

Gambar 2. Peran Identitas Moral Terhadap Perilaku Anti Sosial dengan Moral Disengagement Sebagai Mediator

Perilaku anti sosial merupakan perilaku yang dapat merugikan orang lain karena bertentangan dengan norma sekitar. Perilaku anti sosial yang dilakukan oleh remaja sangat beragam, seperti perusakan lingkungan, mencuri, membolos sekolah, mengkonsumsi alkohol dan obat terlarang, kekerasan fisik, dan prostitusi. Terdapat berbagai faktor munculnya perilaku anti sosial, baik faktor eksternal maupun faktor internal. Dalam penelitian ini, variabel independen yang diteliti sebagai peran terhadap perilaku anti sosial adalah faktor internal, yaitu identitas moral dan moral disengagement.

Hasil analisis regresi memperlihatkan bahwa identitas moral dan moral disengagement secara signifikan berperan terhadap perilaku anti sosial. Keduanya memberikan sumbangan efektif sebesar $12 \%$ terhadap perilaku anti sosial, dengan sumbangan efektif pada moral disengagement sebesar $7 \%$ dan identitas moral sebesar 5\%. Analisis lebih lanjut dengan uji mediasi menunjukkan bahwa moral disengagement memediasi secara parsial hubungan antara identitas moral dan perilaku anti sosial.

Hasil penelitian ini serupa dengan hasil penelitian Hardy dkk. (2015) yang menemukan bahwa perilaku anti sosial berhubungan secara negatif dengan identitas moral. Identitas moral merupakan mekanisme yang ada dalam diri individu untuk menetapkan parameter dalam berperilaku secara moral. Ketika seseorang menetapkan parameter yang tinggi, berarti identitasnya berpusat pada moralitas, sehingga tindakannya akan selalu berdasar pada standar moral. Identitas moral yang kuat akan memunculkan tindakan yang bermoral (Colby \& Damon, 1992). Sebaliknya, identitas yang rendah akan lebih memungkinkan individu untuk berperilaku anti sosial (Hyde dkk., 2010). Orang yang berperilaku anti sosial biasanya tidak mematuhi norma, berperilaku agresif, tidak peduli, dan meyakiti orang lain. Hal-hal tersebut menunjukkan bahwa pada orang yang berperilaku anti sosial, moralitas bukan merupakan pusat dari identitas dirinya.

Moral disengagement merupakan proses individu dalam melakukan hal yang merugikan orang lain yang disebabkan oleh tidak aktifnya moral-self. Moral disengagement akan membuat individu untuk berperilaku tidak etis dan tidak memiliki rasa bersalah ketika melanggar standar 
moral. Menurut Moore (2015), moral disengagement memiliki hubungan yang signifikan dengan perilaku tidak etis seperti intimidasi, agresi, dan perilaku kriminal. Pernyataan tersebut juga sesuai dengan hasil penelitian Kavussanu dkk. (2015) bahwa moral disengagement menjadi prediktor dalam munculnya perilaku anti sosial.

Meskipun identitas moral dan moral disengagement berkontribusi secara signifikan terhadap kemunculan perilaku anti sosial, sumbangannya tidak besar yaitu hanya $12 \%$. Dengan demikian $88 \%$ varians perilaku anti sosial disumbang oleh faktor-faktor lain. Faktor-faktor yang tidak diteliti dalam penelitian ini dapat berupa faktor keluarga, teman sebaya, lingkungan, sosial dan ekonomi, maupun individu. Slattery dan Meyers (2014) menyatakan bahwa faktor masyarakat lebih berpengaruh pada munculnya perilaku anti sosial remaja dibandingkan dengan faktor keluarga dan teman sebaya. Sesuai dengan teori Ekologi (Bronfenbrenner, (dalam Swick \& Williams, 2006) bahwa faktor masyarakat seperti disorganisasi masyarakat, adanya kekerasan pada masyarakat, dan kurangnya kelekatan pada masyarakat memiliki pengaruh dalam membentuk perilaku seseorang.

Farrington dkk. (2001), menemukan bahwa pengaruh yang paling kuat dalam munculnya perilaku anti sosial pada remaja adalah faktor keluarga, khususnya parental discipline. Faktor tersebut dapat menjadi prediktor perilaku anti sosial sebesar 53\%. Begitu juga dengan hasil penelitian McGee dkk. (2011) yang menunjukkan bahwa faktor keluarga yang berupa komunikasi keluarga dan pola asuh menjadi prediktor utama dalam munculnya perilaku anti sosial pada remaja. Menurut Bronfenbrenner dalam Swick dan Williams (2006), keluarga merupakan bagian dari mikrosistem anak yang sangat berpengaruh pada perilaku anak karena keluarga adalah tempat anak mendapatkan pendidikan pertama kali. Bronfenbrenner juga mengatakan ketika anak sudah menginjak remaja, faktor teman sebaya akan lebih berpengaruh pada perilaku dibanding faktor keluarga. Karakteristik teman sebaya akan berpengaruh pada karakter seseorang. Jika seseorang remaja terlibat dalam pergaulan dengan teman sebaya yang sering melakukan kriminalitas, maka kemungkinan remaja tersebut akan mengikutinya.

Hasil penelitian ini juga memberi informasi bahwa perilaku anti sosial remaja usia 15 tahun adalah yang paling rendah yang kemudian meningkat pada usia 16 tahun; kemudian pada rentang usia 16-18 tahun tidak terjadi peningkatan maupun penurunan. Pola ini mungkin berhubungan dengan adanya perubahan aktivitas dopaminergik yang meningkat pada usia 16 tahun, yang mengakibatkan adanya aktivitas pencarian sensasi yang mengarah pada perilaku pengambilan resiko. Di samping itu, menurut Wong dkk. (2013), anak laki-laki di akhir masa kanak-kanak hingga awal remaja cenderung mengalami peningkatan intensitas ketakutan atau kecemasan, sehingga remaja usia 15 tahun perilaku anti sosialnya masih cenderung rendah. Ketakutan dan kecemasan tersebut menurun seiring bertambahnya usia remaja dan membuat remaja menjadi lebih berani dalam bertindak maupun berperilaku, maka aktivitas anti sosial pun meningkat dengan berlalunya usia peralihan menuju remaja sepenuhnya. Temuan mengenai pola perkembangan perilaku anti sosial ini memberikan informasi bahwa upaya-upaya pencegahan perilaku anti sosial sebaiknya dilakukan sedini mungkin sebelum anak memasuki usia 16 tahun.

Lebih lanjut, sebanyak 29\% dari responden penelitian ini menunjukkan perilaku anti sosial dalam taraf sedang hingga tinggi, dan $61 \%$ responden memiliki moral disengagement pada kategori sedang dan tinggi. Hal tersebut merupakan peringatan untuk pihak sekolah, keluarga maupun masyarakat karena angka di atas mengindikasikan adanya potensi yang dapat termanifestasi menjadi perilaku anti sosial yang nyata sewaktu-waktu jika ada provokasi. Perlu dicatat bahwa kedua sekolah yang menjadi tempat penelitian ini bukanlah sekolah yang memiliki catatan perilaku anti sosial yang tinggi pada siswanya; dikhawatirkan potensi tersebut akan lebih tinggi pada sekolah-sekolah tertentu. 
Banyaknya proporsi remaja yang morally disengaged dapat disebabkan oleh memudarnya empati pada remaja saat ini. Remaja yang empatinya rendah cenderung tidak memiliki rasa iba terhadap orang lain, sehingga lebih mungkin untuk melepaskan diri secara moral melalui berbagai mekanisme dalam moral disengagement. Hasil penelitian Hyde (2007), menunjukkan bahwa empati memiliki pengaruh terhadap moral disengagement. Menanamkan kemampuan empati pada anak dan remaja merupakan langkah prevensi yang sangat penting agar mereka tumbuh sebagai pribadi yang tidak mudah terlepas dari nilai-nilai moral.

\section{SIMPULAN}

Penelitian ini menunjukkan bahwa identitas moral yang tinggi dan moral disengagement yang rendah berkontribusi terhadap pencegahan perilaku anti sosial remaja. Pengujian lebih lanjut menunjukkan bahwa moral disengagement ini merupakan mediator bagi peran identitas moral terhadap perilaku anti sosial, meskipun mediasinya bersifat parsial. Perilaku anti sosial remaja meningkat pada usia 16 tahun kemudian stabil hingga usia 18 tahun. Ditemukan pula bahwa 29\% responden menunjukkan perilaku anti sosial dalam taraf sedang hingga tinggi, dan $61 \%$ responden memiliki moral disengagement pada kategori sedang dan tinggi.

Cukup tingginya presentase responden dengan perilaku anti sosial dan moral disengagement dalam taraf sedang hingga tinggi menunjukkan adanya urgensi upaya-upaya pencegahan perilaku anti sosial di kalangan siswa SMA. Upaya yang dapat dilakukan berupa optimalisasi penerapan pendidikan moral yang terkandung dalam kurikulum. Penerapan pendidikan karakter moral diharapkan dapat memberi pengaruh pada meningkatnya identitas moral dan menurunnya moral disengagement pada siswa. Upaya lain yang dapat dilakukan untuk mencegah moral disengagement dapat dilakukan seperti memperketat tata tertib di sekolah. Keluarga memiliki peran penting dalam membentuk identitas moral pada anak, sehingga pengasuhan dalam keluarga seyogyanya memastikan agar anak memiliki moralitas yang melekat pada identitasnya. Orangtua juga selayaknya menjadi teladan dalam menegakkan nilai-nilai moral, agar anak belajar untuk tidak mudah melepaskan diri dari nilai-nilai moral yang dianutnya (morally disengaged).

Untuk peneliti selanjutnya, disarankan pengambilan data dilakukan di komunitaskomunitas atau sekolah-sekolah yang lebih beresiko terhadap perilaku anti sosial dengan jumlah subjek yang lebih banyak.

\section{REFERENSI}

Allsopp, J. F., \& Feldman, M. P. (1976). Personality and anti-social behaviour in schoolboys: Item analysis of questionnaire measures. The British Journal of Criminology, 16(4), 337-351. https:/ / doi.org/10.1093/oxfordjournals.bjc.a046765

Aquino, K., \& Reed, A. (2002). The self-importance of moral identity. Journal of Personality and Social Psychology, 83(6), 1423-1440. https://doi.org/10.1037/0022-3514.83.6.1423

Badan Pusat Statistik [BPS]. (2010). Profil kriminalitas remaja 2010. Diambil dari https://www. bps.go.id/publication/2010/12/30/703312c2e156dd5bbebcb8cc/profil-kriminalitasremaja-2010.html

Badan Pusat Statistik Provinsi Daerah Istimewa Yogyakarta [BPS DIY]. (2019). Statistik politik dan keamanan Daerah Istimewa Yogyakarta 2018. Diambil dari https://yogyakarta.bps.go.id/ 
publication/2019/11/15/4456022b19209daea361 faab/statistik-politik-dan-keamanandaerah-istimewa-yogyakarta-2018.html

Bandura, A. (2002). Selective moral disengagement in the exercise of moral agency. Journal of Moral Education, 31(2), 101-119. https://doi.org/10.1080/0305724022014322

Bandura, A., Barbaranelli, C., Caprara, G. V., \& Pastorelli, C. (1996). Mechanisms of moral disengagement in the exercise of moral agency. Journal of Personality and Social Psychology, 71(2), 364-374. https://doi.org/10.1037/0022-3514.71.2.364

Bandura, A., \& Jourden, F. J. (1991). Self-regulatory mechanisms governing the impact of social comparison on complex decision making. Journal of Personality and Social Psychology, 60(6), 941951. https://doi.org/10.1037/0022-3514.60.6.941

Bandura, A., \& National Institute of Mental Health. (1986). Prentice-Hall series in social learning theory. Social foundations of thought and action: A social cognitive theory. Prentice-Hall, Inc.

Baron, R. M., \& Kenny, D. A. (1986). The moderator-mediator variable distinction in social psychological research: Conceptual, strategic, and statistical considerations. Journal of Personality and Social Psychology, 51(6), 1173-1182. https://doi.org/10.1037/0022-3514.51.6.1173

Burt, S. A., \& Donnellan, M. B. (2009). Development and validation of the subtypes of Antisocial Behavior Questionnaire. Aggressive Behavior, 35(5), 376-398. https://doi.org/10.1002/ ab.20314

Bushman, B. J., \& Baumeister, R. F. (2007). Social psychology and human nature. Boston, US: Cengage Learning.

Colby, A., \& Damon, W. (1992). Some do care: Contemporary lives of moral commitment. New York, US: The Free Press.

Farrington, D. P., Jolliffe, D., Loeber, R., Stouthamer-Loeber, M., \& Kalb, L. M. (2001). The concentration of offenders in families, and family criminality in the prediction of boys' delinquency. Journal of Adolescence, 24(5), 579-596. https://doi.org/10.1006/jado.2001.0424

Feist, J., \& Feist, G. J. (2009). Theories of personality (7 ed.). New York, US: McGraw-Hill.

Hadi, U. (2019). Klitih bacok korban pakai pedang di Yogya, terduga pelaku masih SMP. Diambil dari detikNews website: https://news.detik.com/berita-jawa-tengah/d-4805588/klitihbacok-korban-pakai-pedang-di-yogya-terduga-pelaku-masih-smp

Hardy, S. A., Bean, D. S., \& Olsen, J. A. (2015). Moral identity and adolescent prosocial and antisocial behaviors: Interactions with moral disengagement and self-regulation. Journal of Youth and Adolescence, 44(8), 1542-1554. https:/ / doi.org/10.1007/s10964-014-0172-1

Hardy, S. A., \& Carlo, G. (2011). Moral identity: What is it, how does it develop, and is it linked to moral action? Child Development Perspectives, 5(3), 212-218. https://doi.org/10.1111/j.17508606.2011.00189.x

Harradine, S., Kodz, J., Lemetti, F., \& Jones, B. (2004). Defining and measuring anti-social behaviour. 
London, UK: Home Office.

Hayes, A. F. (2013). Introduction to mediation, moderation, and conditional process analysis: A regression-based approach. New York, US: The Guilford Press.

Hyde, L. W. (2008). Developmental precursors of moral disengagement and a mediator of early risk for antisocial behavior. Pennsylvania, US.

Hyde, L. W., Shaw, D. S., \& Moilanen, K. L. (2010). Developmental precursors of moral disengagement and the role of moral disengagement in the development of antisocial behavior. Journal of Abnormal Child Psychology, 38(2), 197-209. https://doi.org/10.1007/s10802-009-9358-5

Kartono, K. (2009). Patologi sosial 1. Jakarta: Rajawali Pers.

Kavussanu, M., Ring, C., \& Kavanagh, J. (2015). Antisocial behavior, moral disengagement, empathy and negative emotion: A comparison between disabled and able-bodied athletes. Ethics \& Behavior, 25(4), 297-306. https://doi.org/10.1080/10508422.2014.930350

McGee, T., Wickes, R., Corcoran, J., Bor, W., \& Najman, J. (2011). Antisocial behaviour: An examination of individual, family, and neighbourhood factors. Trends \& issues in crime and criminal justice. Diambil dari https://aic.gov.au/publications/tandi/tandi410

Moffitt, T. E., Caspi, A., Rutter, M., \& Silva, P. A. (2001). Sex differences in antisocial behaviour: Conduct disorder, delinquency, and violence in the dunedin longitudinal study. Cambridge, UK: Cambridge University Press.

Moore, C. (2015). Moral disengagement. Current Opinion in Psychology, 6, 199-204. https://doi. org/10.1016/j.copsyc.2015.07.018

Reynolds, S. J., \& Ceranic, T. L. (2007). The effects of moral judgment and moral identity on moral behavior: An empirical examination of the moral individual. Journal of Applied Psychology, 92(6), 1610-1624. https://doi.org/10.1037/0021-9010.92.6.1610

Santoso, B. (2019). Kondisi terkini siswa korban klitih di Sleman Yogyakarta. Diambil dari https:// jogja.suara.com/read/2019/11/08/104014/kondisi-terkini-siswa-korban-klitih-di-slemanyogyakarta

Santrock, J. W. (2017). A topical approach to lifespan development 9 th edition. New York, US: McGraw-Hill Higher Education.

Slattery, T. L., \& Meyers, S. A. (2014). Contextual predictors of adolescent antisocial behavior: The developmental influence of family, peer, and neighborhood factors. Child and Adolescent Social Work Journal, 31(1), 39-59. https://doi.org/10.1007/s10560-013-0309-1

Suharjono. (2019). Bacok mahasiswa, 3 pelajar SMP pelaku klitih di Yogyakarta jadi tersangka. Diambil dari https://yogya.inews.id/berita/bacok-mahasiswa-3-pelajar-smp-pelaku-klitih-di-yogyakartajadi-tersangka

Swick, K. J., \& Williams, R. D. (2006). An analysis of Bronfenbrenner's bio-ecological perspective for early childhood educators: emplications for working with families experiencing stress. 
Early Childhood Education Journal, 33(5), 371-378. https:/ / doi.org/10.1007/s10643-006-0078-y

Wakoli, C., Kiptiony, G., Chemwei, B., \& Chonge, H. (2016). Peer influence on aggressive behaviour of adolescents in secondary schools in Bungoma County. International Journal of Arts Humanities and Social Sciences (IJAHSS), 1(3), 59-66. Diambil dari http:/ / www.ijahss.com/ Paper/11002016/694782560.pdf

Wong, T. M. L., Loeber, R., Slotboom, A.-M., Bijleveld, C. C. J. H., Hipwell, A. E., Stepp, S. D., \& Koot, H. M. (2013). Sex and age differences in the risk threshold for delinquency. Journal of Abnormal Child Psychology, 41(4), 641-652. https://doi.org/10.1007/s10802-012-9695-7

Yuwono, M. (2020). Pemuda di Yogyakarta mengaku iseng lempar cat dan tendang remaja hingga tewas. Diambil dari https://regional.kompas.com/read/2020/01/14/20503151/pemuda-diyogyakarta-mengaku-iseng-lempar-cat-dan-tendang-remaja-hingga?page $=$ all 